\title{
Erratum to: Validity of a New Patient Engagement Measure: The Altarum Consumer Engagement (ACE) Measure ${ }^{\text {TM }}$
}

\author{
Christopher C. Duke ${ }^{1} \cdot$ Wendy D. Lynch ${ }^{2} \cdot$ Brad Smith $^{3} \cdot$ Julie Winstanley $^{4}$
}

Published online: 23 October 2015

(C) Springer International Publishing Switzerland 2015

\section{Erratum to: Patient}

DOI 10.1007/s40271-015-0131-2

The following changes have been made to the text.

Final sentence of Sect. 3.1 should read as follows:

In addition to test criterion validity, respondents were asked to score 13 items that are contained in the Patient Activation Measure ${ }^{\circledR}\left(\mathrm{PAM}^{\circledR}\right)$ [16].

The original article has been updated accordingly.

The online version of the original article can be found under doi:10.1007/s40271-015-0131-2.

Christopher C. Duke

chris.duke@altarum.org

1 Altarum Institute, 3520 Green Ct, Suite 300, Ann Arbor, MI 48105, USA

2 Lynch Consulting, Ltd., Steamboat Springs, CO, USA

3 IMPAQ International, Philadelphia, PA, USA

4 Osman Consulting Pty, Ltd., Sydney, NSW, Australia 